\title{
Farewell to Wolfgang and Carl-Christian, welcome to Alexandra: change of editors in the Journal of Management Control: an editorial
}

\author{
Thomas W. Guenther ${ }^{1}$
}

(C) Springer-Verlag GmbH Germany, part of Springer Nature 2018

By the end of 2017 two long-time editors of the Journal of Management Control retired as editors. We say good-by to Wolfgang Berens and Carl-Christian Freidank. Both served as editors for many, many years and established the proceeding Germanspeaking journal in the German market. It is fair to say that both were also very much interested in further developing the field of management accounting and control and in keeping in touch and in interaction with practice. They accepted the responsibility for countless reviews, also sometimes at very short notice. Wolfgang Berens and CarlChristian Freidank also supported the strategy to internationalize the journal and to enter the global market. Both were always open for new perspectives, approaches or academic fields as their own academic careers show. Wolfgang and Carl-Christian will recently retire from their positions at University of Münster and of University of Hamburg. We are very thankful that we had the opportunity and pleasure to work with them for many years as co-editors of the Journal of Management Control and wish them farewell and all the best for their "second" life outside academia.

To support the further development of the Journal of Management Control, we are happy to simultaneously expand our team of editors. Alexandra van den Abbeele from KU Leuven, Belgium, joined the team of editors. Alexandra van den Abbeele has published in highly ranked journals, such as The Accounting Review, Journal of Management Accounting Research, Accounting, Organizations and Society and Organisational Science. We are happy to have her now in our team of editors.

\footnotetext{
Thomas W. Guenther

thomas.guenther@tu-dresden.de

1 Technische Universität Dresden, Dresden, Germany
} 
In 2017, the following scholars in alphabetical order gave us their support by reviewing submitted papers, and, thus, dedicated their precious time, their expertise and judgement on a voluntary basis to our submitted papers. We are very thankful for this great resource of reviewers of the Journal of Management Control (reviews finished in 2017):

\begin{tabular}{|c|c|c|c|}
\hline Title & Last name & First name & Affiliation \\
\hline Dr. & Bedford & David & University of Technology Sydney, Australia \\
\hline Jun.-Prof. Dr. & Bellora-Bienengräber & Lucia & University of Hamburg, Germany \\
\hline Jun.-Prof. Dr. & Biesenthal & Christopher & $\begin{array}{l}\text { WHU Otto Beisheim School of } \\
\text { Management, Germany }\end{array}$ \\
\hline Prof. & Bisbe Vinas & Josep & ESADE Business School, Spain \\
\hline Prof. Dr. & Brueggen & Alexander & Maastricht University, The Netherlands \\
\hline Prof. & Burns & John E. & University of Exeter Business School, UK \\
\hline Dr. & Clinton & Eric & $\begin{array}{l}\text { Dublin City University Business School, } \\
\text { Ireland }\end{array}$ \\
\hline Prof. & de Villiers & Charl & University of Auckland, New Zealand \\
\hline Dr. & Derfuss & Klaus & Fern Universität Hagen, Germany \\
\hline Prof. Dr. & Dierkes & Stefan & $\begin{array}{l}\text { Georg-August-Universität Göttingen, } \\
\text { Germany }\end{array}$ \\
\hline Prof. Dr. & Duller & Christine & Johannes Kepler Universitat Linz, Austria \\
\hline Dr. & Duncan & Keith & Bond University, Australia \\
\hline Dr. & Endrikat & Jan & TU Dresden, Germany \\
\hline \multirow[t]{2}{*}{ Dr. } & Feeney & Orla & Dublin City University, Ireland \\
\hline & Friestad & Liv Bente & University of Agder, Norway \\
\hline Dr. & Giovannoni & Elena & Royal Holloway University of London, UK \\
\hline Prof. Dr. & Goretzki & Lukas & Handelshögskolan i Stockholm, Sweden \\
\hline Prof. Dr. & Guenther & Thomas & TU Dresden, Germany \\
\hline Prof. & Hartmann & Frank & $\begin{array}{l}\text { Erasmus Universiteit Rotterdam, The } \\
\text { Netherlands }\end{array}$ \\
\hline Prof. Dr. & Hiebl & Martin & University of Siegen, Germany \\
\hline Prof. Dr. & Himme & Alexander & Kuehne Logistics University, Germany \\
\hline Prof. Dr. & Hinz & Michael & Technische Universität Chemnitz, Germany \\
\hline Prof. Dr. & Hirsch & Bernhard & $\begin{array}{l}\text { Universität der Bundeswehr München, } \\
\text { Germany }\end{array}$ \\
\hline Prof. Dr. & Holzhacker & Martin & $\begin{array}{l}\text { Michigan State University, Broad College of } \\
\text { Business, USA }\end{array}$ \\
\hline \multirow[t]{2}{*}{ Prof. Dr. } & Hoozée & Sophie & Universiteit Gent, Belgium \\
\hline & $\mathrm{Ilg}$ & Patrick & Technische Universitaet Dresden, Germany \\
\hline Prof. Dr. & Kajüter & Peter & WWU Münster, Germany \\
\hline Prof. Dr. & Knauer & Thorsten & Ruhr University of Bochum, Germany \\
\hline Prof. Dr. & Kunz & Jennifer & Universitaet Augsburg, Germany \\
\hline Prof. Dr. & Lueg & Rainer & Syddansk Universitet, Denmark \\
\hline Prof. & Lukka & Kari & University of Turku, Finland \\
\hline
\end{tabular}




\begin{tabular}{|c|c|c|c|}
\hline Title & Last name & First name & Affiliation \\
\hline Prof. & Madini & Paola Maria & University of Kent, UK \\
\hline Dr. & Melloni & Gaia & University of East Anglia, UK \\
\hline Dr. & Moilanen & Sinikka & Oulu Business School, Finland \\
\hline Dr. & Nitzl & Christian & $\begin{array}{l}\text { Universität der Bundeswehr München, } \\
\text { Germany }\end{array}$ \\
\hline Prof. Dr. & Obermaier & Robert & Universitat Passau, Germany \\
\hline Jun.-Prof. Dr. & Ott & Christian & Europa-Universität Viadrina, Germany \\
\hline Prof. & Pellinen & Jukka & University of Jyväskylä, Finland \\
\hline Prof. & Perego & Paolo & $\begin{array}{l}\text { Erasmus Universiteit Rotterdam, The } \\
\text { Netherlands }\end{array}$ \\
\hline Prof. & Quinn & Martin & DCU Business School, Ireland \\
\hline Assoc. Prof. Dr. & Reimer & Marko & $\begin{array}{l}\text { WHU Otto Beisheim School of } \\
\text { Management, Germany }\end{array}$ \\
\hline Prof. Dr. & Reimsbach & Daniel & Radboud Universiteit, The Netherlands \\
\hline Prof. Dr. & Rohlfing-Bastian & Anna & $\begin{array}{l}\text { Goethe-Universität Frankfurt am Main, } \\
\text { Germany }\end{array}$ \\
\hline PD Dr. & Sandner & Kai & $\begin{array}{l}\text { Ludwig-Maximilians-Universitat Munchen, } \\
\text { Germany }\end{array}$ \\
\hline Prof. Dr. & Schaeffer & Utz & $\begin{array}{l}\text { WHU Otto Beisheim School of } \\
\text { Management, Germany }\end{array}$ \\
\hline Prof. Dr. & Schiemann & Frank & Universitat Hamburg, Germany \\
\hline Prof. Dr. & Schreck & Philipp & $\begin{array}{l}\text { Martin-Luther-Universitaet } \\
\text { Halle-Wittenberg, Germany }\end{array}$ \\
\hline Prof. Dr. & Speckbacher & Gerhard & Wirtschaftsuniversitat Wien, Austria \\
\hline Prof. Dr. & Strauss & Erik & Universitaet Witten/Herdecke, Germany \\
\hline Prof. Dr. & Stumpf-Wollersheim & Jutta & $\begin{array}{l}\text { Technische Universitat Bergakademie } \\
\text { Freiberg, Germany }\end{array}$ \\
\hline Prof. Dr. & Tillema & Sandra & University of Groningen, The Netherlands \\
\hline Prof. Dr. & van der Kolk & Berend & IE Business School, Spain \\
\hline Prof. Dr. & Wall & Friederike & Alpen-Adria-Universität Klagenfurt, Austria \\
\hline Prof. Dr. & Weller & Ingo & $\begin{array}{l}\text { Ludwig-Maximilians-Universität München, } \\
\text { Germany }\end{array}$ \\
\hline Prof. Dr. & Wentges & Paul & University of Ulm, Germany \\
\hline Prof. & Zeghal & Daniel & University of Ottawa, Canada \\
\hline
\end{tabular}

We start 2018 with an issue which once more represents the wide horizon of our journal covering both different methods (a case study, an analytical paper, and an empirical analysis) and different topics (management control systems in a Kibbutz industry, business valuation, and cost management). This signals at its best the diversity of management control in today's academic research. We like to note that the Journal of Management Control by intention stands for this diversity in methods and topics and intends to be open for a wide range of researchers with different methods, academic backgrounds, schools and perspectives. 
The case study of Yaffa Moskovich examines the strategic choices which are the basis of the business model of a particular privatized Kibbutz factory. Her study focuses on the nature and evolution of the factory's business strategy and discusses how management utilized beliefs controls to implement change and to manage the shift of the Kibbutz factory from the original pure socialist tradition to capitalism. Findings illustrate the gradual evolution of the factory's strategic business model into a hybrid structure that combined the logic of both community and economics.

Following the shareholder value paradigm, two of the most important issues related to value-based management are firm value and the periodic value contribution of a firm, often measured as residual income. Different approaches of residual income have been discussed and used for such valuation purposes and for the performance measurement of firms for many years to link the value of a company to traditional accounting data. Concerning certain financing policies with changing levels of debt-so-called autonomous financing strategies - the problem of circularity has to be solved to readjust the cost of capital. As a practical way to handle this issue Dirk Beyer suggests a matrix-based approach to deal with circularity.

Finally, although the importance of cost management for organisational performance is frequently stressed in the literature, attempts to develop an integrative framework for a cost management system remained on a conceptual level without empirical validation. Additionally, previous research on cost management systems fails to draw on findings from a theoretically more pronounced stream, from the field of management control systems. To fill this gap, the paper of Ulf Diefenbach, Andreas Wald and Ronald Gleich develops a model for a cost management control system relying on both, cost management and management control systems literature. Based on a sample of 251 European firms they explore the relationship of cost management control systems with cost efficiency and organisational performance using structural equation modelling.

We wish the readers of the Journal of Management Control interesting insights, new ideas and finally a lot of fun with the three academic papers in this issue.

Dresden, March 2018

For the team of editors

Thomas W. Guenther

Managing editor 